\title{
The formation of a social Hispanic Atlantic space and the integration of merchant communities following the Treaties of Utrecht ${ }^{1}$
}

\author{
Ana Crespo Solana \\ Instituto de Historia, Consejo Superior de Investigaciones Científicas (CSIC), C/ Albasanz, 26-28, 28037 Madrid, Spain \\ e-mail: ana.crespo@cchs.csic.es
}

Submitted: 10 April 2014. Accepted: 28 May 2014

\begin{abstract}
Current research into Spanish commercial expansion in the Americas has recently turned to a new consideration of space as a historical category. In fact, when the interconnecting processes are analysed, one of the most striking phenomena is the actual "production of the space" in which a wide variety of exchanges took place. This production/creation of space becomes obvious in Spanish colonial commerce. This article discusses the theoretical framework for this spatial perspective, and analyses the impact that this construction of space on the organization of routes and on network formation, as well as its evolution within the institutional context following the Treaties of Utrecht.
\end{abstract}

KEYWORDS: Spanish Colonial Trade; Early Modern History; Merchant Networks; Maritime Routes

Citation / Cómo citar este artículo: Crespo Solana, Ana (2014). "The formation of a social Hispanic Atlantic space and the integration of merchant communities following the Treaties of Utrecht". Culture \& History Digital Journal, 3(1): e007. doi: http://dx.doi.org/10.3989/chdj.2014.007

RESUMEN: La formación del espacio social hispano-atlántico y la integración de las comunidades mercantiles después de los tratados de Utrecht.- Los estudios sobre la expansión comercial española en América han virado recientemente hacia una importante reconsideración del espacio como categoría histórica. De hecho, uno de los fenómenos más interesantes de analizar en los procesos de interconexión global es la "producción de espacio" en el que se producen los intercambios de todo tipo. Esta producción de espacio es evidente en el caso del comercio colonial español. En este artículo se explicará el marco teórico de esta perspectiva espacial y se analizará el impacto de esta construcción de espacio en la organización de las rutas y en la formación de redes así como su evolución en el marco institucional después de los tratados de Utrecht.

PALABRAS CLAVE: Comercio colonial español; Historia moderna; Redes mercantiles; rutas marítimas

Copyright: (C) 2014 CSIC. This is an open-access article distributed under the terms of the Creative Commons AttributionNon Commercial (by-nc) Spain 3.0 License.

\section{INTRODUCTION}

Today, it is widely accepted that during the centuries of European expansion, a social, institutional and scientific space was created at global level which greatly influenced the subsequent evolution of the interconnected societies. Far from being "eurocentrist", the result of this reorientation of history towards a global history is a new social theory on the Atlantic World. This theory highlights the empirical evidence demonstrating that globalization is not a recent phenomenon-although this belief was previously accepted as fact, and still is by some scholars - but an underlying globalization process dating as far back as the $15^{\text {th }}$ century, if not earlier. McNeill states that "macrohistorians grossly overlook most available literary records" (McNeill, 1996: 21). But there is also recent research which, although focused on spaces limited by social, political and economic factors, describes the global connection of various territories by means of a process of selection and critical as- 
sessment of the available sources. The empirical information is drawn from the available sources in order to enable us to respond to questions related to the problems and limitations affecting global interactions within the various spaces (Ringrose, 2001; Parker, 2001). At the same time, a new theoretical framework is being created so as to offer a number of valuable features and pedagogical aids designed to pique students' interest with regard to specific world history topics and help them process and retain key information.

Due to its interesting interdisciplinary approach, one of the major theoretical and methodological lines of research may be the spatial turn. A brief survey of recent publications and scholarly activity focused on discussions of the spatial turn reveals the extent to which it has developed into something of a dominant paradigm (Roberts, 2012: 15). This is obvious when approaching the study of the empires and the various and highly connected Atlantic and global systems which formed around maritime routes and economic centres. Patrick O'Brien has stated that the space which derived from the expansion of western societies and their converging with indigenous societies outside of Europe led to connections and flows, primarily of information, science and the knowledge derived from natural philosophy, and that this led to the so-called western societies in which we currently live (O'Brien, 2013: 1-36). This is an obvious phenomenon when studying Iberian expansion. Between the "First America" (as David Brading calls the Spanish America from which the first Atlantic world emerged as a result of conquest and early colonization by the Iberians) and the port cities of Seville, Huelva and Cadiz, new channels of exchange were opened up. These were ever-changing in terms of time and space. And in those early days of the Hispanization process, three issues merged together in the American Atlantic: race, religion and language. This combination is still an important issue in large parts of the American continents, from Mexico to Patagonia (around 16 million square kilometres at the time). Brazil and its Portuguese culture and language had strong ties with the Spanish side, as Portugal had been part of the Spanish monarchy between 1580 and 1640 (Crespo Solana, 2014).

These processes of interconnection were not homogeneous, but affected by determining factors related to spatial and geographic location. They led to the creation of, among other things, perception-based cartography onto which historical processes and the construction of the social space were projected. Pierre Chaunu has stated that time and space, history and geography rely on one other to provide the beginning of an explanation, and this is essential for a time when inequality, based on a combination of power and race, was the norm in the evolution of historical processes (Chaunu, 1985: 265). The construction of a social space as defined by Henri Lefebvre in his book The Production of Space (1991) does not simply refer to natural geography, nor is it an empty container filled by history. Rather, space includes the importance of spatial relationships. Space and human relations change over the course of history and each in- fluences the other. Lefebvre spoke of "social space" when considering the idea that space and humankind are mutually constituent elements and not separate categories in an abstract model. Relationships are important in the geographic and social construction of history. The work of the historian is in fact dedicated to highlighting this important phenomenon: the relationship between space and mankind. Relationships are categorized and analysed by the movement of human beings through space and this movement is dynamic. The new approach taken since the spatial turn clarifies new concepts related to space. Its importance stems from two issues of significant value for historiography today, as it champions a reconsideration of "space" as a historical and analytical category. Aside from notable exceptions, the study of space as an object had already begun to be found lacking in the majority of previous historical studies, as analyses with a time-based configuration were traditionally given greater consideration. However, space as an object of study was also subliminally present in studies of Atlantic history, as well as the intellectual tradition of historiography on European expansion and global history. Nonetheless, these schools considered the oceans and associated territories around them as cultural and historical constructions overlaid on heterogeneous geography, rather than applying truly scientific economic and social criteria. This idea has been broken open with the publication of a group study on the importance of oceans as a means of communication and global union, while at the same time considering the waterscapes or marine landscapes where human social action takes place not as empty spaces, but as key in analysing global integration and its evolution (Mukherjee, 2013: 3).

Regarding his concept of geohistory, Fernand Braudel states that the physical environment imposes changes and adaptations on man by means of constant or even slight variations (Braudel, 2002: 87). The meaning of time and space is closely linked to the social subject, although events are always considered. Yuan and Stewart (2008) proposed a conceptual premise that synthesizes the concepts of events, processes, activities, change, movement and spatiotemporal data. "An event denotes that something has happened, a process characterizes how it happens, and an activity is an action carried out by an actor. When events and activities take place, they may trigger a process to initiate or become intensified" (Yuan, 2014).

The formation of a Hispanic Atlantic social space went through various stages which were heavily influenced by the social and political evolution of the Spanish monarchy. In addition, global interaction in the Iberian Atlantic was determined by territorial circumstances. In this paper, I will analyse two main factors that are necessary to understand how this Hispanic Atlantic world was shaped as a result of the Treaties of Utrecht. I will share some ideas in relation to whether these treaties led to significant changes in two respects: spatial integrationalong the routes linking Spain with its colonies and the adaptation of the merchant communities around this space. 


\section{SPATIALIZATION AND TRADE ROUTES}

Research into the Iberian empires has highlighted that, although these empires have been regarded as secondary in comparison with the attention other merchant nations have attracted, their Atlantic expansion was one of the most important achievements in world history (Bethencourt and Curto, 2007). As for the Spanish empire, the study of its Atlantic commercial system has only recently been addressed from the perspective of Atlantic historiography (Pietschmann, 2002; Martínez Shaw \& Oliva Melgar, 2005).

However, new lines of research are being explored, looking into the Hispanic presence in the Atlantic world. These chiefly focus on analysis of the transnational flow of ideas coming from Spain to France and England, albeit from an American perspective (Yuste López, 1997; Hill, 2005; Romano, 2004), or from the perspective of the relationship between merchants and the state (Pérez Sarrión, 2012). A very good book published recently by Cardim, Herzog, Ruiz Ibáñez and Sabatini (2012) highlighted the importance of the movement of peoples, models and ideas in establishing an Iberian political legacy at a global level. The Hispanic expansion developed and was built around a licence-based trading system which was overseen and inspected by the Crown of Castile - although privately run - and which delimited a number of areas of production and markets in Spain and the Spanish America. This expansion was a dynamic spatial model which evolved into self-sustaining locational structures (Crespo Solana, 2014). And the resulting spatial structure was perhaps what primarily influenced the logistics infrastructures that other mercantile empires put in place when they came to pursue their own respective expansions. The extensive route which began in Andalusia - its path to America departing from South Andalusia - and linked the Canary Islands, the Antilles, various areas around the Caribbean (especially Mexico and Venezuela), southern Florida, the coastal areas of the South American Cone, and various areas in Sub-Saharan Western Africa supplying slaves, constituted and consolidated a large integrated zone made up of various regions. In certain contemporary documents, this Atlantic space was referred to as the "Hispanic Sea" (Pietschmann, 2010). Not all of these regions participated equally in the global economy which emerged from this trade. Their integration, to a greater or lesser extent, continues to be a reason for synergies, asymmetries and unequal exchange. A great many merchant networks from other European nations were also operating within this space, on occasions as competitors and real enemies, but also at other times as valuable collaborators.

Institutional development and the spread of trade routes were the hands that modelled this newly created system. Beginning in the early stages of the consolidation of the Spanish empire in the Americas, the monarchy devised certain mechanisms - revised and reformed several times over the centuries - with the purpose of encompassing these newly found territories.
Proof of this is the series of administrative and institutional measures implemented with the object of gaining total knowledge and control of the new lands. In addition to this, the entire empire was processed cartographically according to the contemporary perception of these kingdoms in the Indies. It is well known that the bureaucratic burden had been very heavy since the times of Philip II. This process also had a scientific bias, as all the empire's civil servants and officials had to account for the dimensions of the territories through empirical, direct knowledge. As had been foreseen by Francis Bacon, there was no longer any boundary between geographic expansion and science. ${ }^{2}$

Spanish colonial trade followed a route which ran across the Atlantic from the ports of Andalusia to the Canary Islands and then on to the Antilles. It then forked off in the direction of the approved ports for the two viceroyalties: Peru and New Spain. The Spanish Crown created legislation (influenced mostly by the economic elite close to the kings of Castile) stating that the colonization and exploitation of the Americas was a private enterprise, but with collaboration and fiscal supervision from the Crown by means of a few institutions created for this purpose. Spanish colonial trade between the $16^{\text {th }}$ and $18^{\text {th }}$ centuries was an undertaking which was intended to be a state business (subject to monopolies and licences), but privately financed. This was a model which had previously been developed in Europe when commercial traffic took place within a particular area, as in the case of Cantabrian trade with Flanders (Flanders Route and Eastern Route from the Middle Ages onwards), trade with the Hansa, or even Portuguese trade from the $14^{\text {th }}$ century. In 1569 , the two fleets were clearly identified: the Flota de Nueva España (Fleet of New Spain), with a final destination in the port of Veracruz (required to set sail from Spain in the month of April); and the fleet headed for the continent (Galleons of Terra Firma), bound for Nombre de Dios - a port later replaced by Portobelo (Panama) - which was to depart in August. Every year, these two fleets spent the winter in the Indies and met in March at the port in Havana to undertake the return ocean crossing to the peninsula together (García-Baquero González, 1992).

This system remained in operation until almost 1765 . Prior to this date, there were a number of attempts to reform the shipping systems in a bid to curtail the monopoly enjoyed first by Seville and then by Cadiz. It seems contradictory that the change of dynasty in Spain following the War of Succession and the resulting attempts to exclude the English and the Dutch from the Indies trade led to tighter controls, both military and fiscal, being imposed on Cadiz, as the city was a major centre for foreign trade. There were many efforts to reform this system between 1720 and 1765 - such as the anonymous "Memorial a S.M. sobre que el comercio es la riqueza y el mayor poder de las potencias del mundo, 1721" " "Memorandum to His Majesty regarding commerce being the wealth and might of the world's major powers"), which did not gain much support 


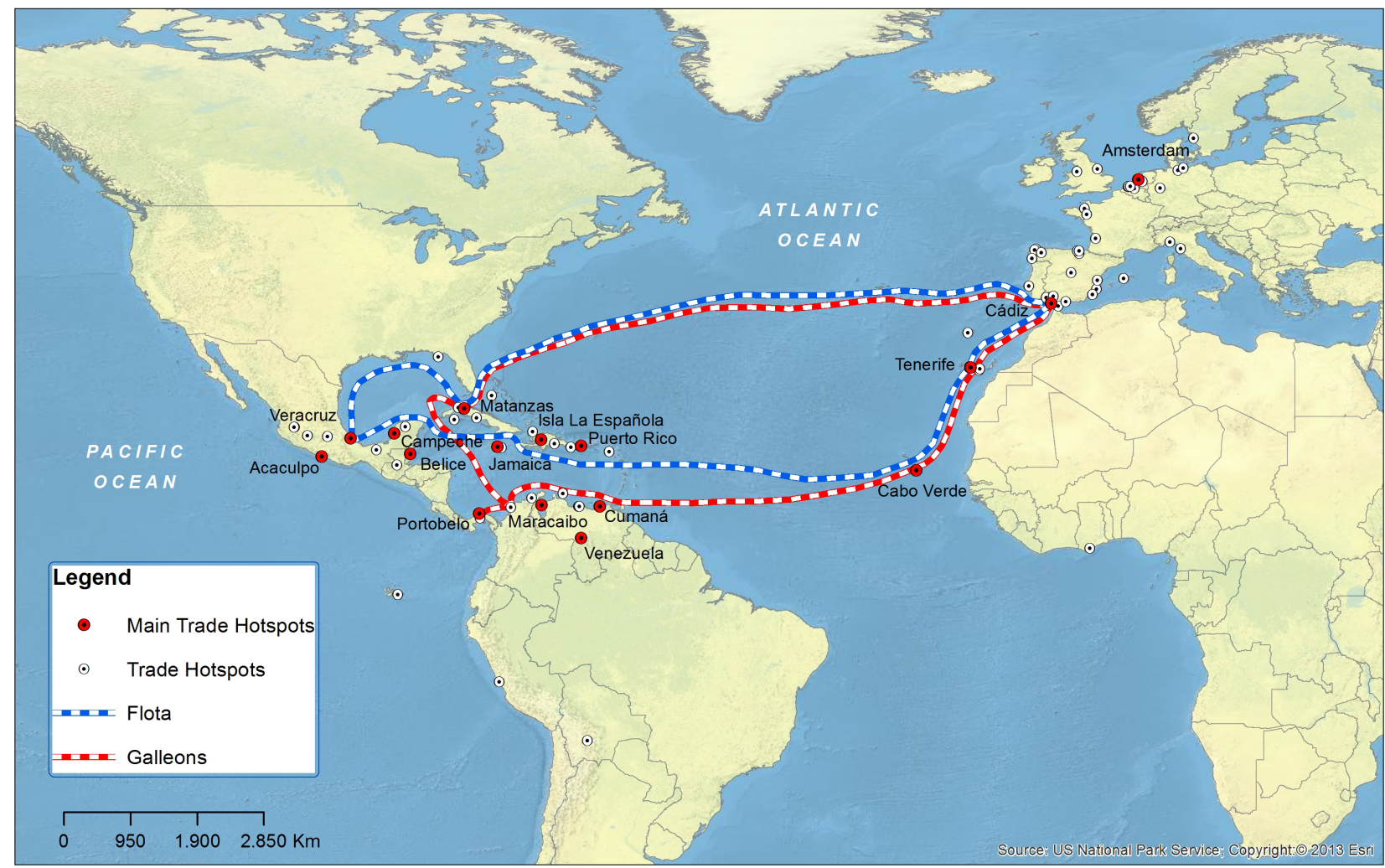

MAP I. Routes of the Fleets and Galleons

(Delgado Barrado, 2003: 185-213). ${ }^{3}$ Despite its rigidity, this system was improved through subsequent reforms, such as the addition of individual register ships in the time of Philip V. This affected intraregional trade within the Caribbean (Map 2).

As part of an extensive spatio-temporal process, this system was built around trading networks that are shaping the spatial configuration (Middell, 2010; Krugmann, Fujita and Venables, 1999). By using new technologies such as GIS - Geographic Information Systems - we are now able to visualize, and analyse, these networks with the object of gaining valuable insight into how the spatial and economic organization of trading networks influenced the integration of maritime spaces and relationships among the numerous trading areas that formed the Hispanic commercial system. The available data on Portuguese and Spanish expansion are the testing grounds for this new tool. ${ }^{4}$ With regard to this analytical model, we are asking the following question, which relates the organization of trade networks to the construction of a social space in the Hispanic Atlantic: How did the commercial systems of the mercantile nations in the $17^{\text {th }}$ and $18^{\text {th }}$ centuries influence the formation of structures and types of territorial organization?

The Portuguese case has been analysed by Amándio Barros. He states: "networks redesigned geography, or better, created their own geography through an actual destruction of the space" (Barros, 2014). He goes on to say that this "destruction of space", crossing political frontiers and disregarding cultural and religious boundaries, recommended itself to Iberian merchants and networks if they wanted to succeed in the competitive early modern trading world.

As for the Hispanic Atlantic, in order to grasp how these trade networks were organized, we must bear in mind that the Atlantic was the setting for continuous migratory processes. Migratory waves multiplied within Europe proper from the mid-16 $6^{\text {th }}$ century, for religious, political and/or socio-economic reasons. The demographic growth seen in many commercial cities, together with the creation of a young labour force and the emergence of new socio-professional categories, turned these cites into key institutional spaces in which mercantile capitalism was consolidated (Pipitone, 2003). The $18^{\text {th }}$-century Hispanic Atlantic reveals certain features related to the growth seen in some cities. These include the monopolistic role played by Cadiz, driven by the colonies of foreign merchants living there, and the opposing forces against this monopoly driven by the internal, social and economic synergies that emerged around Spanish trade in the Atlantic.

Bourbon policies also gave other port cities in Spain direct or indirect access to colonial trade, like Barcelona, Malaga and Alicante. In addition, capital and trading cities in America were stimulated. The consulates 
The formation of a social Hispanic Atlantic space and the integration of merchant communities following the Treaties of Utrecht 5

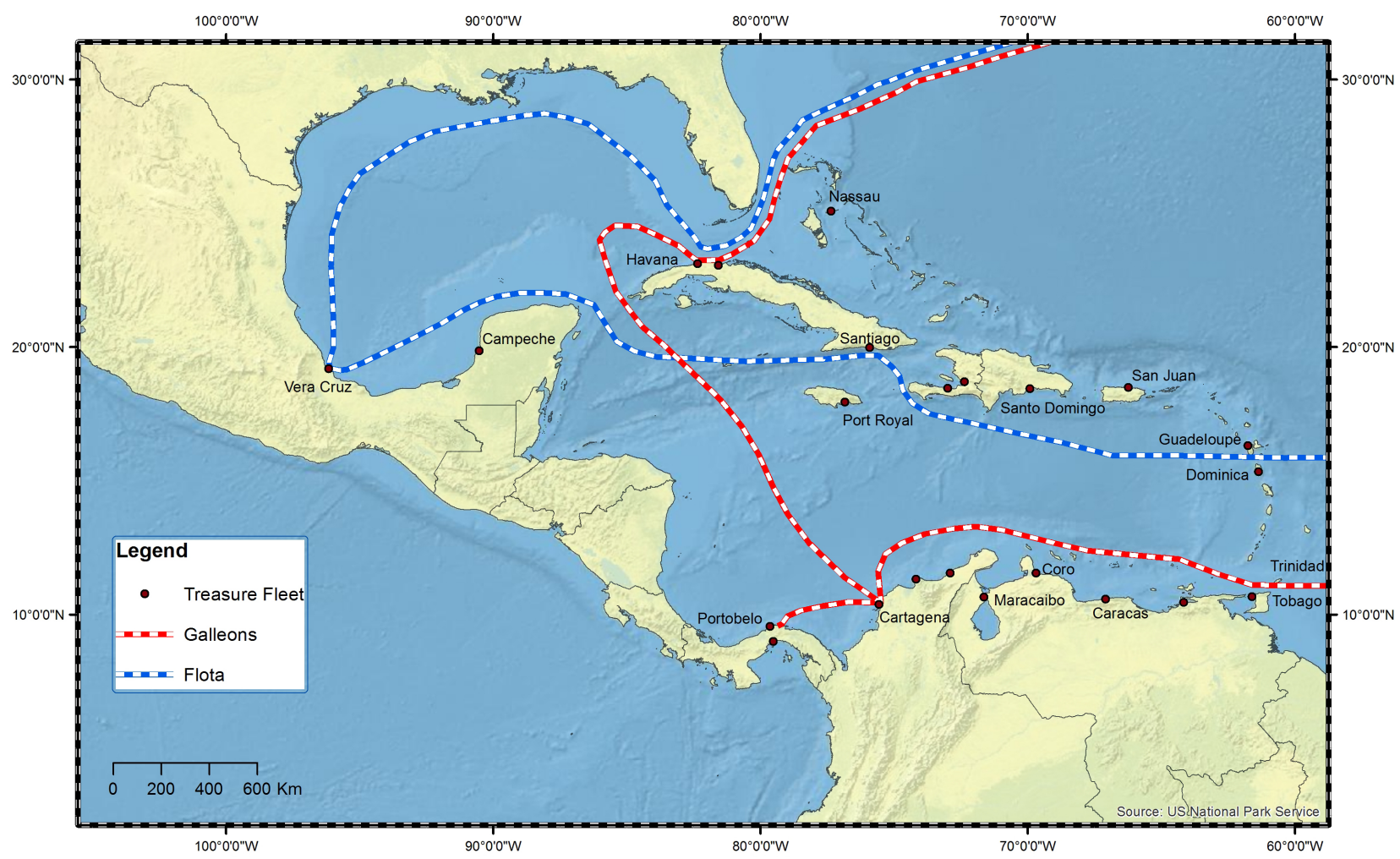

MAP 2. Trade in the Caribbean and the subsidiary fleets

(merchants' guilds) in Mexico and Lima were allowed to continue as they had enormous power in political and economic affairs. A consulate was also created in Veracruz.

One of the most important subjects to be considered when attempting to understand the complexity of the connections at both socio-institutional and economic levels relates to the role played by trade communities of different nationalities based in various urban centres in Europe and the Americas linked to the Atlantic economy, along with large trading companies in Asia and Africa. Historiography has also highlighted the importance and features of these merchant communities, how they worked and were structured around this system of global interaction, establishing a close relationship between the phenomenon of migration, the formation of trading companies and the evolution and integration of various socio-cultural and economic areas, together with the role played by these groups in economic transformation (Mauro, 1993; Subrahmanyam, 1996; Crespo Solana, 2011). Furthermore, it has been possible to create a theoretical model for the study of trade communities and their impact on the evolution of these companies, as well as their influence on political and diplomatic relations between modern states. These studies have evolved from traditional macro-economic works (Chaunu, 1956-1959) or analyses of European trading companies in the colonial world or the Spanish trade with the Americas (Emmer, Petre-Grenouilleau, Roit- man, 2006; Bustos Rodríguez, 2005; Crespo Solana, 2010 b). In this line of research, which aims primarily to study the role played by merchant networks, important developments have undoubtedly been made, but it is still possible to make further progress on issues related to geographic, conceptual and methodological aspects, as pointed out by Ramada Curto and Molho (2002).

A good part of the existing studies on the Spanish commercial system - as much in the Atlantic as, to a lesser extent, in the Asia-Pacific area of influence (due to trade with the Philippines) - make reference to how trade networks operated in these areas. Many studies on this topic describe the emergence of new forms of cooperation and competition among economic agents and how merchants developed mechanisms for trade and cooperation. Commerce in the first global age was characterized by high rates of smuggling. This was not possible without cooperation and close relationships between agents who on most occasions lived very far apart from each other and had never met one another. In most commercial port cities, these agents formed an oligopoly and almost always previously had or had developed ties of kinship through marriage or patronage by means of various mechanisms of symbiosis and integration. Even when formal commercial agreements could be ratified before a notary, these were frequently hard to enforce and their validity depended heavily on the willingness of the parties to cooperate with each other. For this reason, trust and reputation were crucial 
factors in understanding merchant behaviour in social environments. Therefore, the behaviour of merchants, financiers and others involved in the development of commercial networks will provide evidence of cooperation in trading activity, which has not been considered in other studies. Global trade between the $16^{\text {th }}$ and $18^{\text {th }}$ centuries would not have been possible without the emergence of new forms of human behaviour, cooperation, defection or competition, depending on the complex dynamics in which this evolution took place.

The integration of the Atlantic World was closely related to how merchant networks were organized. John Elliot spoke of an "integration of communities" but failed to explore its full meaning. In actual fact, the family networks of merchants who were involved in economic activities in Spain and its colonies developed entrepreneurial mechanisms with the purpose of protecting their businesses - depending to a lesser or greater degree on their nationality and the historical junctures that influenced their behaviour. Those merchants that migrated to Spanish cities had to develop forms of cooperation and symbiosis - very often beyond religious, ideological and/or identity-related sympathies - which allowed them to interact with other families with similar interests, and become integrated into contemporary Spanish society. This specific issue must be further discussed from the perspective of "social networks". Despite the massive amount of empirical data which historians have so far gathered on merchant networks in the early modern era, we are still in the process of developing theories and conceptual frameworks with which we can link the data gathered to a theoretical argument from both a sociological and historical perspective (Van Young, 2011: 289-309; Crespo Solana and Alonso García, 2012).

A "social network" can be described as an "informal association of a group of people based on a relationship of trust and a continuous exchange of services or favours within a reciprocal system". And this is indeed what an adequate "social environment" provides in terms of elements of informality, trust-based relationships, exchange and reciprocity. ${ }^{5}$ However, I would also add the relative absence of actual credit (hard cash) required for businesses in order to fulfil the internal needs of these networks and market demands, rather than to meet the political interests of the nations. In my opinion, the former premise (which is patently obvious when the colonies of foreign merchants in Spain involved in colonial trade are studied) is central when it comes to "tracing connections", as argued by John Elliot (2001), and to finding opportunities to compare empires and being able to understand the role played by certain communities in the Atlantic world as a whole.

In general, the foreign merchant communities settled in Spain played an important role in this Hispanic Atlantic scenario. In the words of Fréderic Mauro: "the study of merchant communities represents the sociological dimension of research on "merchant empires"" (Mauro, 1990: 255-285). And this is clear in the case of the merchant colonies in Spanish cities involved in the Carrera de las Indias (Indies Route), such as Seville or Cadiz. Recently, I was able to show how these networks operated within the Spanish Empire (Crespo Solana, 2010a: 181-314). The entrenched urban nature of these colonies meant that many merchant families were susceptible to the various historic processes that took place in early modern Europe between the $16^{\text {th }}$ and the $18^{\text {th }}$ centuries as a result of religious wars, structural changes in the economic development of different regions and the emergence of new representatives and forms of political power. Due to their role in the economic development and integration of regions and markets, the existing literature places great importance on issues such as their ability to control monopolies, their ability to act as both private traders and as part of merchant companies, and their activity within the economic system. They organized themselves into cooperative and competing social networks. From this perspective, because of their economic activity, the colonies of foreign merchants promoted spatial economic integration and maritime routes between the various European markets and between these and the colonies. In fact, the merchant communities were essentially local urban groups which created trading organizations displaying strong solidarity and fraternal ties amongst their members. They established monopolies and created a way to pass on their commercial skills. This fact is essential to understanding Spanish expansion into the Atlantic region. Studies also point to certain aspects relating to the population characteristics of these groups and to their family relationships, not to mention the complex aspects arising from socioeconomic and institutional research. To understand the Spanish case, French, German, English and Flemish communities established in Spain have been examined and their study has highlighted some interesting discrepancies in relation to the current state of research on foreign colonies (Hausberger and Ibarra, 2003). For example, attention has been drawn to the difficulty in defining such contradictory terms as nation, merchant colony or consulate. The first refers directly to the community itself, with its internal hierarchy and fraternal bonds, its members linked by family, economic and social relationships (the latter nearly always based on the institutional system and a shared religion), as well as common geographic and linguistic origins. More studies have been carried out on this subject. ${ }^{6}$ Consulates, on the other hand, were organizations imposed by the Spanish Crown based on its diplomatic interests at a given time, but they did not always favour the interests of the merchant communities established in the Hispanic Atlantic (Crespo Solana, 2011: 373-403).

\section{HOW NETWORKS FUNCTIONED}

In the case of Cadiz, networks can be analysed as the local hub for the activities of these merchant networks. Cadiz was a port city and a derivatives market: this would explain certain peculiar phenomena in rela- 
tion to the Indies trade. According to some historians, such as Clé Lesger and others, this dual function would turn the region into a "gateway system", that is, a hub within an integrated economic spatial system where external trade was conducted through specialized middlemen. This would reveal that there was a kind of specialization that would exclude other economic sectors, or that the market structures themselves, the dynamics of the flow and the metal trade would have an oligopsonic nature. This specific situation occurs in markets where a very few traders have a lot of market power and there is a small number of buyers acting as an elite that exercises maximum control over prices and the amount of products to be made available on the market. Therefore, profits would primarily go to the buyers (in most cases these buyers are middlemen) rather than the producers. As a result, the situation of the latter worsens because they do not receive a reasonable price for their products (Nogués-Marco, 2010).

This economic reality - with a fundamentally social background - makes it obvious that foreign merchants were not alien to the Spanish monopoly. Quite the contrary, they were the most eager supporters/sponsors at a time when Spain kept its depleted Atlantic empire only with permission from Europe. They functioned as intermediaries in an oligopsonic - as well as oligopolic market whose main features were the alliances, interdependence and coexistence that characterized the true nature of the relationship between Spaniards and foreigners, except on few and rare exceptional occasions.

What was most needed in a frontier society with high levels of smuggling was cooperation. This cooperation was not at all incompatible with competition among the various networks connecting the different market areas and the various financial centres. Here you would see the richest and most powerful businessmen monopolizing a traffic that was highly characterized by a black market in metals. This market was coordinated by foreigners, mostly transient agents involved in the purchase and sale of goods with the object of accumulating silver. A great number of these middlemen were related to each other. Such traders would fix market prices, undercutting the official price of silver. In order to move contraband, it was necessary to utilize legal strategies that would disguise the appearance of smuggling. These strategies operated in close symbiosis with the law and the ambiguous, or at least not very clear, regulations that the monarchy wished to implement in order to maintain this alleged monopoly or state business under its control at all costs. It was these networks that shaped the social and even the institutional aspects of the American Atlantic that emerged after Utrecht.

\section{MAINTAINING THE EMPIRE UNTIL 1765}

After the Treaties of Utrecht, a new dynamic system began to consolidate around the Spanish trading system in the Atlantic as a result of various articles in the treaties. There was a "before" and "after" Utrecht, as this historical series of events led to a divergence in the Hispanic Atlantic world. The contents of the articles regarding the Spanish empire in the Americas and its commercial system began to be written back in the mid$17^{\text {th }}$ century. At that time, the continued existence of the Spanish Hapsburg monarchy was brought into question, as was the system imposed in the Atlantic by the old politico-imperial structure. This system was intended to leave nothing for the other merchant nations but the peripheral territories discarded by the Spaniards. In 1705, the Auditor General of the Spanish Board of Trade (Junta de Comercio), Bernardo Tinajero, admitted: "It can be said that what foreign nations own in the Americas is but the worst and most barren and only what the Spaniards decided not to keep and populate. ${ }^{7}$ However, he also admitted that those foreign nations had succeeded in creating and developing powerful navies and wealthy colonies "to and from which vessels sail in such numbers that princes make use of them and their crews whenever they see fit". ${ }^{8}$

Eloquent voices of concern regarding the possible loss of the Indies were raised. Among them was the Marquis de Varinas, writing in his memorial. Also, the fear of ports being attacked was voiced by merchants and published in several pamphlets at the time. Perhaps it was this fear that led the people of several territories in the Spanish empire to welcome Philip V. A prominent example is Catalonia, where in 1701, the Courts received the king and pledged to support him. This resulted in Barcelona being granted permission to send two ships a year to the Americas without registering them in Seville. Among the other benefits gained by the Catalans was the creation of a Universal Maritime Merchant Company inspired by the Dutch companies (Sanz Ayán, 2013: 189). Several of these rewards were maintained, despite the extremely heavy repression later suffered by the former kingdom of Aragon. The dynastic change allowed Catalonia to become part of the Spanish Atlantic world and also set in motion what would later become Catalonia's industrial revolution (Martínez Shaw, 1981).

Colonial and commercial interests were already on the agenda at the preliminary peace negotiation that took place in April 1711 in London. Even in the 1699 and 1700 Partition Treaties, such interests were taken into account. The $19^{\text {th }}$ of August 1712 brought the signing of a truce and armistice between Great Britain, Spain and France, in which provisions were made to return any people or property captured to Britain. It was also agreed that Gibraltar and Port Mahon would remain in British hands and that Britain was allowed to moor its own warships there for protection. In March 1713, a peace and trade treaty was signed between England and Spain, without the involvement of France. In it, Menorca was added to the concessions in recognition of an earlier period of Anglo-Spanish collaboration. In this agreement, the English were granted a contract to supply black slaves. They were allowed to store their "merchandise" in the River Plate under the supervision of a Spanish official. This treaty also included other privileges gran- 
ted to the English nation, which were later extended to Dutch merchants with businesses in Spain (Cantillo, 1843: 15).

Access to the Americas was a crucial point in the agreements reached at Utrecht, and regulations were established to ensure that only England had access to Spanish America: "... and it has been so established, in order for this rule to be observed, that under no license or appointment shall the French, or indeed any other nation, be permitted to directly or indirectly sail to the American territories belonging to the Spanish king and trade in negroes, goods, merchandise or any other thing" (Cantillo, 1843: 77). English merchants were granted economic privileges and tax exemptions in certain towns and cities, as they had requested before the war. This was now endorsed by Philip V in an agreement signed on the $14^{\text {th }}$ of December 1715 . Further trade agreements were signed between 1713 and May 1716. Spain could not afford to surrender sovereignty over her colonies or alienate her territories to other nations. It may be said that Utrecht allowed Spain to maintain her colonial empire with the consent of the remaining interested nations, as they had made inroads into the intricate, supposedly monopolistic, Spanish commercial system.

Many mysteries related to Spain and Spanish America as a result of the dynastic transition occurred during the reign of Philip V. The Nueva Planta Decrees and the reform of the Spanish commercial system have been thoroughly studied and revisited, but never seen as a direct consequence of the Treaties of Utrecht. Spain's territories were reconfigured as ancient privileges and charters (fueros) were abolished by the Nueva Planta Decrees. The old peninsular kingdoms were made obsolete and Spain was divided into captaincies general in a successful attempt to both militarize and centralize state administration. Almost all of these captaincies were governed by the same law, with the exception of the old viceroyalties, such as Navarre, in which this new territorial arrangement was required to coexist with the ancient fueros. In addition, the Leyes de Extranjería (ImmigrationLaws), whereby a citizen of one Iberian kingdom was a foreigner in any of the other Iberian kingdoms, were abolished. This in fact enabled the Catalans to trade directly with the Americas.

Despite French interference, several Spanish statesmen, including Tinajero de la Escalera, attempt to tackle the Achilles' heel of the Spanish colonial system: widespread corruption as most civil servants operated as front men and allies to private merchants. In a report circulated in July 1707 at the Board of Trade, Tinajero exposes how the consulates engendered significant losses for the royal treasury by recording incorrect information with regard to the cargoes of all fleets and galleons since 1689 . It is worth noting that 1689 was identified as the earliest year for which they were capable of collecting sufficient hard evidence. ${ }^{9}$ Repeated fraudulent figures reported by the Consulate of Seville were one of the reasons that led the Board of Trade to relocate to Cadiz, along with the consulate. In this port city, it would be easier to enforce the newly created via reservada system - later implemented by Patiño - by means of new regulations. This system was an attempt by the institutions in charge of the fleets to liaise directly with the crown. This minor innovation - largely ineffective in the end - was seen by Patiño as the only way to tax American cash advantageously, given the impossibility of undertaking a full reform of the shipping system while the 500-tonne license issued to English merchants following Utrecht was in force. Patiño himself admitted that until 1744 at the earliest, it would not be possible to change it (Delgado Barrado, 2003). The crown insisted on colonial trade being a "state business", but it was also aware of the enormous power held then and in the future by the communities of foreign merchants operating out of Cadiz. Bernardo Tinajero de la Escalera himself admitted the need to operate in harmony with foreigners, thus showing the crown's willingness to fully participate in the lobby of Cadiz. It would never be possible for the state to be a major player on the commercial stage in Seville, due to the power of the local aristocracy. Documents seized from the secretary and accounting office of the Consulate in Seville which were held by its agent Cristobal Esquerra (books for the fleets from 1689 to 1705$)$ reveal an underlying issue: there were several parties in the Seville aristocracy aligned either for or against the new Bourbon government.

The Indies trade was solely in the hands of Seville's Consulado de Cargadores - an all-powerful merchants' lobby - but they saw that this was about to change in favour of the foreign merchants involved in the Indies trade by means of networks and consignees in Cadiz. There were also French agents who frequently visited the court in Madrid, and English as well as Dutch merchants had extended their networks to Hispanic American ports. Seville's consuls were accused of "having committed continuous excesses, misused their powers and given no account for their actions, in breach of royal orders and resulting in harm to commerce and loss to the royal treasury". ${ }^{10}$ These factors are central to understanding the events that occurred subsequently and the changes in the government of the Viceroyalty of New Spain, especially after the appointment of Francisco Fernández de la Cueva, Duke of Alburquerque, as new viceroy. He was also in charge of building the trading posts that would be used by the French company responsible for the slave trade in the Spanish colonies. He also seized property and goods belonging to English and Dutch merchants in Mexican ports, as well as those belonging to Portuguese Jews (Escamilla González, 2001: 157-178). In addition, the decisions made by the Board of Trade led to the creation of an intendancy structure in Spain with the object of taxing American cash for the defence and support of the empire. This system was implemented in 1711 and had a clear French influence. The Junta de Restablecimiento del Comercio (Trade Reestablishment Council) ruled that the Seville consulate did behave unfairly in not supporting this defence, which was favourable to the control measures implemented by 
French merchants in most Spanish port cities, from Cadiz to Veracruz. It was then estimated that the consulate had evaded a total of 645 million pesos in taxes. ${ }^{11}$

It is important to note that as a result of the repeated fraudulent accounting, Philip V ordered the seizure of all documentation from the consulate and sent the consulate's agent at court to prison, as well as some former consulates. All of this fraud compelled the crown to change the system for collecting cash from the Americas. The Auditor General issued a number of dispatches in 1706 to ensure that the cash belonging to the imprisoned officials on board the fleets and galleons leaving Cadiz would be seized on arrival in America and then sent back to swell the war treasury. ${ }^{12}$ The king left court to oversee the war in Aragon and appointed four ministers to the cabinet: Antonio Ronquillo, García Pérez de Araciel, Pascual de Villacampos and Cándido de Molina. They were commissioned to resolve any difficulties in all matters related to the consulate, and to prevent the cash from the Indies from being distributed in the American ports by the fleets' deputies (representatives), who also worked for private, usually foreign, merchants. The pre-existing, high amount of corruption quite simply soared as a result of the power vacuum during the succession crisis and subsequent war.

The Board of Trade was intent on clearing up this mess so that the Royal Treasury could receive its due and changing the system to be able to provide enough cash to the Navy, something the Seville consulate had never been interested in, as its only concern appeared to have been keeping as much cash as it was able to. ${ }^{13}$ Part of the fraud consisted of the fleets' deputies charging a higher rate at the American ports than what was declared upon return to the Spanish ports, and pocketing the difference. On occasions, cash was stolen while the fleet was under attack or after an accident, such as when the Vigo fleet commanded by Manuel de Velasco was shipwrecked off the coast of Galicia. In the Canary Islands, the fleets' deputies charged an extra $2 \%$ on all outbound merchandise as well as "on all merchandise coming from the Indies on board loose (unregistered) ships". ${ }^{14}$

The reform of the Consejo de Indias (Council of the Indies) in 1719 was a reflection of the substantial change that the institutions responsible for the Indies trade were undergoing. Once it was officially relocated to Cadiz in 1717 - in practice the move had began in 1660 - the Casa de la Contratación (Board of Trade) shared part of its responsibilities with the newly created Intendencia General de Marina (Naval Intendancy), an agency in charge of certain naval and fiscal affairs related to the fleet system (Crespo Solana, 1996). The Board of Trade agreed on a series of budgets that would change the structure of port control for the Indies trade, routes and their corresponding ports, and the merchants' activities themselves. It was decided that a Secretary of State should be appointed, a person "as prudent, able and experienced as can be found in the Navy, in the Indies trade or in commerce in general, and general regulations must passed with regard to these departments".

It was also decided that all departments would be furnished with intendancies, police inspectors, navy bookkeepers, shipyards, factories and warehouses for weapons and ammunition for warships, for which the best port locations had to be found. This was the main reason why the Bay of Cadiz was chosen. The board was already in favour of this option, and Jose Patiño also had his own reasons: "[Cadiz] boasts a bay which is rightfully depicted as both beautiful and extensively frequented by vessels of all nations; this bay is ideally located in the event of a war and best suited to conduct the Indies trade as this is one of the largest trades in the world." The idea was to make Cadiz into a massive naval base with intendants, inspectors, etc. Patiño also pointed out that Cadiz was not suitable for large-scale shipbuilding due the high price of hardware, timber and labour, but only suited for occasional maintenance and repairs on a small number of ships. Furthermore, the bay had three or four canals which were blocked with debris. They could be cleared up and the banks reinforced with lime and stone in the French fashion. This way each storehouse would have its own mooring under a sign with its name and the expenditure was certain to pay for itself in a very short time. ${ }^{15}$

Intendants would be in charge of naval inspectors, royal clerks and warehouse keepers, and would be responsible for visiting all the kingdom's shores and ports, as well as training a corps of high-ranking officers who would be on stand-by, ready to go whenever they were needed. Spain had a shortage of naval officers, so they had to be recruited from among foreigners from any country. This new policy was intended to educate and train companies of naval soldiers as well as appoint a general Navy Treasurer.

At the same time, new regulations were passed to restore colonial trade. ${ }^{16}$ These regulations stipulated that only Spanish merchants and their vessels were allowed to sail to and enter American ports. The subjects of any other crown were prevented by law and their ships would not be permitted to enter ports in the Indies. Along with foreign friends and allies, they would be allowed to send merchandise to the Indies by means of a Spanish merchant and by using a Spanish vessel - even if the ship was foreign made. Foreign nations did issue public announcements prohibiting their citizens from sailing to Spanish America, as they would be left to be punished by the Spanish authorities if caught. All persons allowed to trade were entitled to ship all legal merchandise to Cadiz, where it would be taken to the customs office to be checked, "but no tax or duty will be levied on merchandise, clothing or produce of any kind any longer, as the customs officers will only be responsible for checking". Also, all ships from allied nations which arrived in Cadiz had to register their merchandise with the customs officers and state within 48 hours, the consignee responsible for the load. All merchandise bound for the Indies was subject to an export tax known as the almojarifazgo. 
The system of fleets and galleons was maintained as per the 1720 Royal Plan, which was intended to strengthen this main maritime route. However, changes taking place in American intraregional trade led to this system failing and being replaced by a system of "loose" register ships, which allowed for a substantial increase in Hispano-American commerce. This new system did not prevent foreign nations from increasing their already obvious involvement in the Indies trade (Delgado Ribas, 2007: 77).

The greatest impact that Utrecht had on colonial trade resulted from granting England the right to supply African slaves to the Spanish colonies. The English crown gave this licence to the South Sea Company. This company also obtained a licence to send a 500-tonne ship full of merchandise consigned by English merchants to the Americas. ${ }^{17}$ This was the final nail in the coffin for Spain's control over American trade, as it meant that foreign merchants controlled most of this commerce and Spain totally lost what small amount of control it had had over its colonial trade.

The Nueva Planta Decrees were also applied in America. The previous Leyes de Indias (Laws of the Indies) and the encomienda land grant system were abolished, and the internal organization of the viceroyalties was significantly altered (Muro Orejón, 1967). It has been said that setting up captaincies general was based on the territorial structure in France at the time. However, the changes enforced in the Americas by the Bourbon ruling were directed against the power of the creole aristocracy, although the viceroyalties were maintained and a even new one was created. New Granada was created in 1717 by Philip V as a reward for the loyalty shown by America. The Viceroyalty of Peru was also reduced in size, as it had previously comprised most of South America. New viceroyalties were created in Buenos Aires and Santa Fe, and captaincies in Chile and Caracas. Other areas were split off and allocated to a different viceroyalty. In 1718 , the vast region between the River Tumbez and Quito was assigned to New Granada (Vadillo, 2006: 113). Buenos Aires was the only port suited for the trade with Spain, although it was in fierce competition with Montevideo, as the latter was located on a bay more suitable for large draught ships. Spain had been colonizing Montevideo since 1724 in an attempt to drive the Portuguese away from the Sacramento colony (Angelis, 1836).

Bourbon reforms in the Americas led to significant territorial expansion, despite the demographic deficit in several areas. This expansion was the result of missionary as well as military activity, driven by the Bourbon desire to get ahead of the expected invasions by other nations already settled in the Americas, which threatened the weak and barely guarded borders. During the entire $18^{\text {th }}$ century, the Spanish crown continued to be on the defensive in the Caribbean and the northern provinces of the Viceroyalty of Mexico. Naval policy in the Americas was strengthened as a result of the continuous state of colonial warfare and harassment of the Spanish colonies by foreign nations, especially in the Caribbean and the Gulf of Mexico, amongst other things. The Anglo-French war in America led to several, largely unimportant, territorial changes, but placed England in an advantageous position after the 1763 Treaty of Paris. In addition, Spain and Portugal were at war again over control of the River Plate and this led to further borderrelated disagreements. England was all too ready to take advantage of this and increased its smuggling activities in various areas.

However, at a political level there was a change of approach to the "Indian kingdoms" as a result of the Hispanic Monarchy's loss of the European empire when the Treaties of Utrecht were enforced: the Americas at last became the object of more well-planned policies. Antonio Domínguez Ortíz has stated that "the Spanish government became aware that promoting its American empire was the only way to remain a great power, hence the subsequent reorganization and expansion which greatly altered the physiognomy of Spanish America (Domínguez Ortíz, 2010: 41). Despite the wars endured during the $18^{\text {th }}$ century, the Spanish empire enjoyed a period of commercial prosperity. This prosperity was not interrupted when the Cadiz monopoly ended. On the contrary, the increase in wealth spread to other areas of the peninsula. It has been said that the $18^{\text {th }}$ century represents the highest peak for both Spanish colonial domination in the Americas and Spanish trade itself.

\section{NOTES}

1. This research has been funded by the Spanish Ministery of Science and Innovation (MICINN), GlobalNet (Ref: HAR2011-27694).

2. Instauratio Magna, by Francis Bacon was published in 1620 . Quoted by Brendecke, 2012: 16 - 17.

3. Biblioteca Nacional de España [BNE], Mss. 18.055, fols. 239-240.

4. Barros, Polonia, Pinto, Riveiro, in Crespo Solana, 2014: 102-140, 140-178.

5. This has been specified in the theoretical and methodological introduction to: Crespo Solana, coord., 2010, Introduction: 15-29.

6. Further reading about the social and economic framework of merchant communities in: Salas Aussens, 2009; Weber, 2001: 169-174; Hancock, 1995; Gestrich \& Schulte Beerbühl, 2011; Ramada Curto \& Molho, 2002; Crespo Solana, 2010a, 2012 and 2014 .

7. BNE Mss. 12055 , fol. $187 \mathrm{v}$.

8. Ibidem.

9. BNE Mss. 12055.

10. BNE, Mss. 12055, fol. 2.

11. BNE, Mss. 12055, fol. 66 .

12. BNE Mss. 12055 , fol. 62

13. "Extracto individual de todas las cuentas que hay que tomar y deben dar los consulados de la ciudad de Sevilla desde el año de 1689 según el Real Decreto de S.M.”.

14. BNE, Mss. 12055, fol. 105

15. Report signed in Madrid, May $15^{\text {th }}, 1713$ by Juan de Monsegur. 
16. "Ordenanzas nuevas que se han de publicar y observar para el comercio y tráfico de las Indias entre los vasallos de estos Reinos con los de aquellos dominios en que se comprenden así los vasallos mis súbditos que estaban excluidos de este comercio como todas las naciones con que se tuviesen alianzas, paz o amistad"

17. Archivo General de Indias [AGI], Sevilla, Indiferente General, 2769, L. 8. "Asiento ajustado entre las dos majestades Católica y Británica sobre encargarse la Compañía de Inglaterra de la introducción de esclavos negros en la América española por tiempo de 30 años".

\section{REFERENCES}

Angelis, Pedro de (1836) Colección de obras y documentos relativos a la antigua y moderna de las provincias del Río de La Plata. Tomo III, Imprenta del Estado, Buenos Aires.

Barros, Amandio Jorge (2014) "Northern Portuguese Commercial Networks and the Geographies of Trade in the Early Modern Period". In Spatio-Temporal Narratives. Historical GIS and the Study of Global Trading Networks (1500-1800), edited by Crespo Solana, Ana. Cambridge Scholar Publishing, London: 102-140.

Bethencourt, Francisco and Ramada Curto, Diogo (editors), (2007) Portuguese Oceanic Expansion, 1400-1800. Cambridge University Press, Cambridge.

Braudel, Fernand (2002) Las ambiciones de la Historia. Crítica, Barcelona.

Brendecke, Arndt (2012) Imperio e Información. Funciones del saber en el dominio colonial español. Iberoamericana Vervuert, Madrid and Frankfurt am Main.

Bustos Rodríguez, Manuel (2005) Cádiz en el sistema atlántico. La ciudad, sus comerciantes y la actividad mercantil. Sílex, Madrid.

Cantillo, Alejandro del (1843) Tratados de Paz convenios y declaraciones de paz y de comercio que han hecho con las potencias estranjeras los monarcas españoles de la casa de Borbon. Imprenta de Alegría y Charlain, Madrid.

Cardim, Pedro; Herzog, Tamar; Ruiz Ibáñez, José Javier and Sabatini, Gaetano (editors), (2012) Polycentric Monarchies: How Did Early Modern Spain and Portugal Achieve and Maintain a Global Hegemony?. Sussex Academic Press, Eastbourne.

Chaunu, Huguette and Chaunu, Pierre (1955-1959) Séville et l'Atlantic, 1504-1650, 8 vols. A. Colin, Paris.

Chaunu, Pierre (1985) Historia, Ciencia Social: La duración, el espacio y el hombre en la época moderna. Ediciones Encuentro, Madrid.

Crespo Solana, Ana (1996) La Casa de la Contratación y la Intendencia General de la Marina en Cádiz (1717-1730). Universidad de Cádiz, Cádiz

Crespo Solana, Ana (2010a) "Legal Strategies and Smuggling Mechanisms in the Trade with the Hispanic Caribbean by Foreign Merchants in Cadiz: the Dutch and Flemish Case, 1680-1750", Jahrbuch für Geschichte Lateinamerikas / Anuario de Historia de América Latina, 47: 181-314.

Crespo Solana, Ana (coordinator), (2010b) Comunidades transnacionales. Colonias de mercaderes extranjeros en el mundo atlántico, 1500-1830. Doce Calles, Madrid.

Crespo Solana, Ana (2011) "El interés público y el interés particular: una visión comparativa en las representaciones de los mercaderes flamencos en la Corte de Felipe V". In Agentes e identidades en movimiento. España y los Países Bajos, siglos XVI-XVIII, edited by Vermeir, René; Ebben, Maurits and Fagel, Raymond. Sílex, Madrid: 373-403.

Crespo Solana, Ana and Alonso García, David (coordinators), (2012) Self-Organizing Networks and GIS Tools. Cases of Use for the Study of Trading cooperation. Journal of Knowledge Management, Economics and Information Technology (JKMEIT), Special Issue, June.

Crespo Solana, Ana (2014) "The Wider World: Spatial expansion and integration in the Hispanic Atlantic, $16^{\text {th }}$ to $18^{\text {th }}$ centuries".
In Spatio-Temporal Narratives. Historical GIS and the Study of Global Trading Networks (1500-1800), edited by Crespo Solana. Cambridge Scholar Publishing, London: 1-45.

Delgado Barrado, José Miguel (2003) "Pensamiento económico y sistemas de navegación colonial. Del puerto exclusivo a las habilitaciones portuarias (1720-1765)". In Naves, puertos $e$ itinerarios marítimos en la época moderna, Actas, edited by Ribot, Luis and de Rosa, Luigi, Madrid: 185-215.

Delgado Ribas, Josep María (2007) Dinámicas imperiales (1650-1796). Ediciones Bellaterra, Barcelona.

Domínguez Ortíz, Antonio (2010) América y la Monarquía española. Comares, Granada.

Emmer, Pieter C.; Petre-Grenouilleau, O. and Roitman, Jessica V. (2006) A Deux ex Machina Revisited. Atlantic Colonial Trade and European Economic Development. Brill, Leiden.

Escamilla González, Iván (2001) "La memoria de gobierno del virrey Duque de Alburquerque, 1710". Estudios de Historia Novohispana, vol 25, No. 25: 157-178.

García-Baquero González, Antonio (1976) Cádiz y el Atlántico, 1717-1778, El comercio colonial español bajo el monopolio gaditano. Diputación Provincial, Cadiz.

García-Baquero González, Antonio (1992) La Carrera de Indias. Suma de la Contratación y océano de negocios. Algaida, Seville.

Gestrich, Andreas and Schulte Beerbühl, Margrit (editors), (2002) Cosmopolitan Networks in Commerce and Society, 1660-1914. Bulletin, Supplement No. 2, German Historical Institute, London.

Hancock, David (1995) Citizens of the World. London Merchants and the Integration of the British Atlantic Community, 1735-1785. Cambridge University Press, Cambridge.

Hausberger, Bernd and Ibarra, Antonio (editors), (2003) Comercio $y$ poder en América colonial: los consulados de comerciantes, siglos XVII-XIX. Iberoamericana Vervuert, Madrid and Frankfurt am Main.

Hill, Ruth (2005) Hierarchy, Commerce and Fraud in Bourbon Spanish America: A Postal Inspector's Exposé. Vanderbilt University Press, Nashville.

Krugmann, Paul; Fujita, Masahisa and Venables, Anthony (1999) The Spatial Economy - Cities, Regions and International Trade (July 1999). MIT Press, Cambridge, Mass.

Martínez Shaw, Carlos (1981) Cataluña en la Carrera de Indias, 1680-1756. Crítica, Barcelona.

Martínez Shaw, Carlos and Oliva Melgar, José María (2005) El sistema atlántico español. Marcial Pons, Madrid.

Mauro, Fréderic (1990) "Merchant Communities, 1350-1750". In Long-Distance Trade in the Early Modern World, 1350-1750, edited by Tracy, James D., Cambridge University Press, Cambridge: $255-285$.

McNeill, William H. (1996) The Rise of the West. A History of the Human Community. The University of Chicago Press, Chicago.

Middell, M. (2010) "Global history and the spatial turn: from the impact of area studies to the studies of critical junctures of globalization". Journal of Global History, 5: 149-170.

Mukherjee, Rila (2011) Networks of the First Global Age. Primus Books, Delhi.

Muro Orejón, Antonio (1967) "Legislación general de Felipe V para las Indias". Revista del Instituto de Historia del Derecho Ricardo Levene, 18: 81-104.

Nogués-Marco, Pilar (2010) Tipos de cambio y tipos de interés en Cádiz en el siglo XVIII (1729-1788). Estudios de Historia Económica, 58. Banco de España, Madrid.

O'Brien, Patrick (2013) "Historical Foundations for a Global Perspective on the Emergence of a Western European Regime for the Discovery, Development and Diffusion of Useful and Reliable Knowledge". Working Papers, n 176/13, March: 1-36.

Parker, Charles H (2001) Global Interactions in the Early Modern Age. Cambridge University Press, Cambridge.

Pérez Sarrión, Guillermo (2012) La Península Comercial. Mercado, redes sociales y Estado en España en el siglo XVIII. Marcial Pons Historia, Madrid.

Pietschmann, Horst (2010) "The Spanish Atlantic in an Age of Transitions". Jahrbuch für Geschichte Lateinamerikas, 47: 345-360. 
Pietschmann, Horst, (2002) Atlantic History. History of the Atlantic System, 1580-1830. Vandenhoeck \& Ruprecht, Cologne.

Pipitone, Ugo (2003) Ciudades, naciones, regiones: los espacios institucionales de la modernidad. Fondo de Cultura Económica, México.

Polonia, Amélia; Pinto, Sara and Riveiro, Ana Sofía (2014) "Trade Networks in the First Global Age. The case study of Simón Ruiz company: visualization methods and spatial projections". In Spatio-Temporal Narratives. Historical GIS and the Study of Global Trading Networks (1500-1800), edited by Crespo Solana, Ana, Cambridge Scholar Publishing, London: 140-178.

Ramada Curto, Diogo and Molho, Anthony (editors), (2002) Commercial Networks in the Early ModernWorld, EUI Working Papers, HEC, No. 2.

Ringrose, David (2010) Expansion and Global Interaction, 1200-1700. Longman, New York.

Roberts, Les (2012) Mapping Cultures. Place, Practices and Perfomance. Palgrave Macmillan, Basingstoke.

Romano, Ruggiero (2004) Mecanismo y elementos del sistema económico colonial americano, siglos XVI-XVIII. El Colegio de México. Mexico City.

Salas Aussens, José Antonio (2009) En busca de El Dorado. Inmigración francesa en la España de la Edad Moderna. Universidad del País Vasco, Bilbao.
Sanz Ayán, Carmen (2013) “Causas y consecuencias económicas de la Guerra de Sucesión española”. Boletín de la Real Academia de la Historia, tomo CCX, cuaderno II: 187-225.

Subrahmanyam, Sanjay (1996) Merchant Networks in the Early Modern World. Variorum, Aldershot.

Vadillo, José Manuel de (2006) La independencia de América: apuntes sobre los principales sucesos que han influido en el estado actual de la América del Sur. Fundación Mapfre, Madrid.

Van Young, Eric (2011) "Social Networks: A Final Comment". In Redes y negocios globales en el mundo ibérico, siglos XVI-XVIII, coordinated by Böttcher, Nikolaus; Hausberger, Bernd and Ibarra, Antonio. Iberoamericana Vervuert, El Colegio de México, Mexico City: 289-309.

Weber, Klaus (2001) "German Merchants in the Atlantic: Trade and Colonial Goods and European Manufactured Goods, Linking Hamburg, Cadiz and Bordeaux (1700-1830)". Jahrbuch für Europäische Überseegeschichte 1: 169-174.

Yuan, Yuan (2014) "Temporal GIS for historical research". In Spatio-Temporal Narratives. Historical GIS and the Study of Global Trading Networks (1500-1800), edited by Crespo Solana, Ana. Cambridge Scholar Publishing, London: 45-56.

Yuste López, Carmen (1997) Comercio marítimo colonial: nuevas interpretaciones y últimas fuentes. Instituto Nacional de Antropología e Historia, Mexico City. 